\title{
Regional differences of border geo-cities in China and the surrounding countries
}

\author{
HU Hao ${ }^{1,2,3}$, WANG Shufang ${ }^{3},{ }^{*}$ GE Yuejing ${ }^{3}$ \\ 1. The Center for Modern Chinese City Studies, East China Normal University, Shanghai 200062, China; \\ 2. Institute of Urban Development and Research, East China Normal University, Shanghai 200062, China; \\ 3. Geo-studies Center, Faculty of Geographical Science, Beijing Normal University, Beijing 100875, China
}

\begin{abstract}
As the improvement of international status and the implementation of China's neighboring diplomacy, the development of border regions and the security of border cities, as well as their spatial structure and regional differences are gaining more attention from academic circle. Based on the interdisciplinary perspectives of urban geography, regional economics and geopolitics, this paper explores the regional differences of border geo-cities in China and the surrounding countries with the help of remote sensing information acquisition and ArcGIS spatial analysis. Three primary results are found as follows: (1) The border geo-cities in China and surrounding countries are divided into five geographical regions: geo-cities in South China Sea, geo-cities in Southeast Asia, geo-cities in South Asia, geo-cities in Central Asia and geo-cities in Northeast Asia. (2) In the spatial structure system of China's border geo-cities, the importance of geo-cities in five major regions is fairly different. In terms of the security and economic development, the rank of priority is geo-cities in Northeast Asia, geo-cities in South China Sea, geo-cities in Central Asia, geo-cities in South Asia, geo-cities in Southeast Asia. (3) Considering China's geo-setting for the development of border geo-cities, the east region is significantly better than the west, and the north region is slightly better than the south.
\end{abstract}

Keywords: geo-setting; regional difference; border regions; border geo-cities; China and the surrounding countries

\section{Introduction}

As the rapid development of society and economy, the international status and influence of China are increasing continuously. With the policy implementation of creating "an amicable, secure and prosperous neighborhood", as well as the guide of China's diplomacy, which can be summarized as "great nations are the key, peripheral nations are the first, developing countries are the foundation, multilateral relationship are the stage", the security and harmo-

Received: 2016-11-29 Accepted: 2017-05-17

Foundation: The National Natural Science Foundation of China, No.41171097, No.41701133; Major Program of National Social Science Foundation of China, No.16ZDA041; The Special Foundation of China Postdoctoral Science, No.2016T90168

Author: Hu Hao (1984-), PhD and Associate Professor, specialized in urban and regional development. E-mail: bsdhao@126.com

"Corresponding author: Ge Yuejing (1963-), Professor, E-mail: geyj@bnu.edu.cn 
nious development of border areas have become the focus of national strategies. Chinese government pays more attention to the stability in border regions, along with the security and development of border geo-cities. The implementation of current national macro strategies in border regions is the issue of geo-setting in essence, to which the security and development of border cities are related. National macro strategies include western region development, the priority of border development, cross-border economic cooperation and sub-regional cooperation. In 2014, National Plan New Urbanization proposed clearly the key construction of border port cities facing Northeast Asia, Central Asia, West Asia, Southeast Asia and South Asia. In this context, some questions are put forward: What is the border geo-setting for urbanization of China and the surrounding countries? What are the spatial pattern and distribution characteristics of border geo-cities? What is the rank of priority for the security and development of border geo-cities? These scientific questions coincide with the demands of current national macroscopic geopolitics, economic development strategy and regional microscopic development policy. Furthermore, they are also the important research questions of urban geography, geopolitical environment and regional development in new period. Therefore, this paper aims to explore the spatial pattern and characteristics of regional differences of border geo-cities, predict the security of China's surrounding geo-setting and provide data support and theoretical reference for further development of border cities.

The research of border geo-cities can be roughly classified into the following five aspects in international academic circle. The first one is the research on the development of "twin cities" in border region. Riitta et al. (2008) divided border cities into two main types: paired border cities that in close proximity (Buursink, 2001), and twin cities that in close cooperation (Kosonen and Loikkanen, 2005). Because paired border cities have received considerably less attention than the broader cooperation in border region (Ehlers et al., 2001), the study of twin cities seems more popular and well known in academic research. There are more than 30 twin cities of cross-border cooperation between the USA and Mexican border regions. Thus, the scholars in Europe and the US focused on case study and model research of cross-border cooperation such as San Diego-Tijuana, Paso-Cd. Juarez, Calexico-Mexicali and Los Indios-Matamoros (Wu, 2011). Laura Mark and Phillip (2009) ever described the development trend of twin cities between the US and Mexico through regional classification of cities, model calculation of urban growth, and development mode. In Russia, Anishenko and Sergunin (2012) regarded Tornio-Haparanda, Valga-Valka, Narva-Ivangorod and Imatra-Svetogorsk as the successful cases of cross-border cooperation of twin cities in the Baltic Sea Region. They pointed out that twin cities should be a new form of cross-border cooperation. In Europe, case studies also happened in German-Polish border (Krätke, 1999), the Finnish border facing Russia, Sweden and Estonia (Eskelinen and Kotilainen, 2004; Lunden and Zalamans, 2001). In China, researchers paid close attention to the coordinated development between Hong Kong and Shenzhen in the early 1990s (Yan and Leng, 1997). But until recently, the Sino-Russian cooperation of twin cities between Heihe city and Blagoveshchensk had been developed and attracted the attention of international community (Mikhailova, 2013).

The second aspect is the social risk study of border cities. Marcelli and Cornelius (2001) studied the migrants' change of border cities between the US and Mexico. Saira (2014) ex- 
amined the role of socio-cultural factors on depression among the elderly of twin cities (Rawalpindi and Islamabad) of Pakistan. Shi et al. (2009) assessed the potential contributors to ozone episodes of the three populated US-Mexican border twin cities, namely San Diego/Tijuana, Imperial/Mexicali and El Paso/Ciudad Juárez. Cheryl et al. (2015) studied the border effects on DSM-5 alcohol use disorders on both sides of the US-Mexican border.

The third aspect is the research on cooperation effectiveness and impact factors of border cities. Hanson (2001) considered that the growth of export processing industry in the Mexican border cities increased the employment, goods and services in American border cities due to the bilateral cooperation of border cities between the US and Mexico. Ramos et al. (2009) considered that the society and environment in US-Mexican border cities had great influence on AIDS infection in this area. Dürrschmidt (2006) took the border cities between German and Poland as a case study, and proved the cooperation effect of border cities spurred by the cultural and political openness.

The fourth aspect is the collaborative research of cross-border cities. Some scholars applied the principle of coordinated development in multi-center cities and twin cities to cross-border cities (Champion, 2001; Meijers et al., 2014). For example, Simon and Grant (2004) studied recent developments in cross-border post-secondary education in the Asia-Pacific region. Wu (2012) took transnational mega city in Bussan Fukuoka region of Northeast Asia as an example and studied the successful conditions for the international exchanges and the network cooperation of cross-border cities. Odile (2001) studied the cooperative potentiality of Dover in UK and Calais in France, which was considered as bi-national cities. Guo (2012) studied the environment cooperation in the US-Mexican Border.

The fifth aspect is to explore the research of framework, theory and method about border cities. Markus (2005) proposed a framework for analyzing rescaling processes and applied it to a case study of the Dutch-German EUREGIO cross-border region. Fanni, Khakpour and Heydari (2014) applied the evaluation method of TOPSIS (Technique for Order Preference by Similarity to Ideal Solution) to the case study of Sistan and Baluchistan provinces in Iran. Johnson (2009) summarized the characteristic of instability and vulnerability of cross-border region in Central Europe. Heyman (2001) classified the cities in the US-Mexican border region. Miguel et al. (2014) proposed a system dynamics model for analyzing the uncertainty caused by delays and disruptions at the US-Mexican border.

Reviewing the existing Chinese literatures about border areas in the last 20 years, we found the importance of border cities research has increased gradually since the related research subjects of geo-setting were proposed in the 1990s, such as regional ports, border, frontiers and so on. The scholars in different fields researched border cities from the perspectives of their respective disciplines, which broadened the theoretical framework of border geo-cities. Urban geography scholars studied the scale and structure of border cities from the perspectives of urban spatial structure, urban land use and urban functional planning (Zhou and Zhang, 2001; Zhang and Li, 2002; Li, 2010; Wu et al., 2012). Regional economic scholars studied the cooperation of port cities from the perspectives of regional development, sub-regional economic cooperation and radiation and impetus of regional development (Guo, 2009; Gu, 2010; Ma, 2011; Song and Wang, 2006). Geo-setting scholars studied the function and mechanism of border cities from the perspectives of regional envi- 
ronment of urban development, the marginal effects of urban growth, the security of geopolitics and geo- economics (Zhu et al., 2011; Fang et al., 2011; Hu Z D et al., 2012; Hu H et al., 2012).

Although the domestic and foreign literatures have analyzed the types, functions, scale, cooperation and effects of border cities from different perspectives, the theoretical exploration lacked the systematic concept involving all port cities and border cities. The summary about the overall characteristics and development law of border cities, the research with the perspective of geo-setting, along with the comparative analysis of regional differences are scarce. Therefore, according to theoretical and realistic demands, together with previous achievements from the projects "China's surrounding geo-setting analysis" and "Construction of digital surrounding and the key technology of geo-setting analysis", this paper tries to explore the regional differences of border geo-cities in China and the surrounding countries from the perspectives of urban geography, regional economics and geopolitics. First of all, the paper reviews related literatures and put forward scientific research questions. The second section proposes core concepts and study object. In this section, border geo-cities in China and the surrounding countries are classified considering the integrity of regional system and the comprehension of sea-land coordination. The third section introduces research idea and method. The remote sensing information acquisition and ArcGIS spatial analysis are used in this paper. The fourth section is results and discussion. The spatial distribution of border geo-cities is explored in both quantitative and qualitative ways. What's more, the regional differences of border geo-cities development are demonstrated, and the driving factors are revealed. The final section is conclusions and future research.

\section{Concepts and study object}

\subsection{Geo-cities}

Based on some basic theories of urban geography and the overall perspective of geo-setting, along with borders and administrative divisions, geo-city is defined as the gathering place of non-agricultural industry and non-agricultural population which is promoted by location, connection and the integrated environment among neighboring countries and regions. "Geo" is the prefix of "geo-cities" which intends to express the "place" and the "relation" of cities in the geographical space and the man-land relationship. And the scope of cities is determined by urban location, economic flow, network, transportation, and social connection. Geo-city is a comprehensive concept, which includes not only border port city, border city, opening city along the border, coastal open city, frontier city with location advantage, but also non-border port city, national center city, regional center city, provincial administrative center city, international friendship city, world tourism city with foreign connection advantage (see Table 1). Compared to other cities, geo-cities have the incomparable security and development conditions on politics, economy, culture, technology, ethnic group, military, national defense, diplomacy, tourism etc. They play an essence role on national security and stability, the regional patterns of opening up and development as well as its urban system construction.

\subsection{Border geo-cities}

Based on the connotation of geo-cities from different perspectives, border geo-cities refer to 
Table 1 Connotation and distribution of geo-cities

\begin{tabular}{|c|c|c|}
\hline Perspectives & Type of cities & Comments or examples \\
\hline \multirow{5}{*}{$\begin{array}{l}\text { Based on } \\
\text { "place" } \\
\text { perspective } \\
\text { or location } \\
\text { advantage }\end{array}$} & Border port cities & Cities with border ports \\
\hline & Border cities & Dandong, Baishan, Yanji, Tumen, Heihe, Yining, Ruili etc. \\
\hline & Border open cities & $\begin{array}{l}\text { Heihe, Hunchun, Manchuria, Yining, Tacheng, Ruili, Hekou, Dongxing, } \\
\text { Dandong etc. }\end{array}$ \\
\hline & Coastal open cities & $\begin{array}{l}\text { Tianjin, Yantai, Nantong, Shanghai, Guangzhou, Shenzhen, Zhuhai, } \\
\text { Shantou, Xiamen etc. }\end{array}$ \\
\hline & Frontier cities & Cities involving 9 land border provinces and 12 coastal border provinces \\
\hline \multirow{4}{*}{$\begin{array}{l}\text { Based on } \\
\text { "relation" } \\
\text { perspective or } \\
\text { connection } \\
\text { advantage }\end{array}$} & Cities with railway ports & Ji'an, Tumen, Dandong, Suifenhe, Dongguan, Foshan, Zhaoqing, Harbin etc. \\
\hline & Cities with highway ports & $\begin{array}{l}\text { Bole, Cangyuan, Dongning, Hunchun, Yoshita, Nielamu, Huocheng, } \\
\text { Tengchong, Tumenetc. }\end{array}$ \\
\hline & Cities with air ports & $\begin{array}{l}\text { Beijing, Shanghai, Tianjin, Chongqing, Fuzhou, Guangzhou, Shenzhen, } \\
\text { Nanning, Guilin etc. }\end{array}$ \\
\hline & $\begin{array}{l}\text { Cities with water } \\
\text { transportation ports }\end{array}$ & 137 cities with open water transportation ports \\
\hline \multirow{5}{*}{$\begin{array}{l}\text { Based on } \\
\text { "geo-setting" } \\
\text { perspective }\end{array}$} & National center cities & Beijing, Tianjin, Shanghai, Guangzhou, Chongqing \\
\hline & Regional center cities & Shenyang, Nanjing, Shenzhen, Wuhan, Chengdu, Xi'an \\
\hline & Provincial center cities & Capital cities of 31 provinces \\
\hline & World tourism cities & $\begin{array}{l}\text { Beijing, Chengdu, Dalian, Hangzhou, Luoyang, Kunming, Nanjing, } \\
\text { Shanghai, Xi'an etc. }\end{array}$ \\
\hline & $\begin{array}{l}\text { International friendship } \\
\text { cities }\end{array}$ & 441 cities which have friendly relations with 1433 foreign cities \\
\hline
\end{tabular}

the cities locating in border areas covering border port cities, border cities, coastal city and border city, frontier cities with prominent national boundary characteristics (Figure 1). Geo-cities in the paper include not only border cities in China, but also foreign cities bordering China. These cities with special geographical locations are the centers of population flow, resource flow, commodity flow and information flow. The opening up and development of these cities directly impact regional development, even national

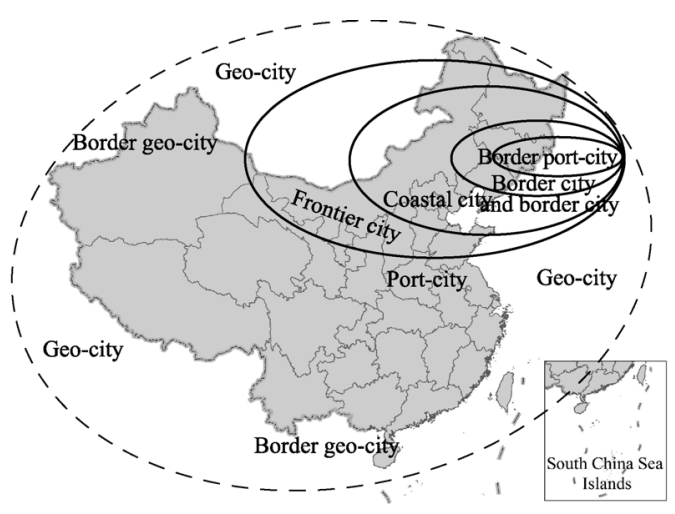

Figure 1 The scope of border geo-cities security and development decisions.

\subsection{Classification of border geo-cities in China and the surrounding countries}

In this paper, geo-cities in China and the surrounding countries are regarded as a complete regional system. Considering the location differences of coast and land, together with the world geographical regionalization and geopolitical situation, the paper divides geo-cities into 2 basic types and 5 geographical regions. One type is coast bordering based on the classification standard of island line ownership, mainly referring to the South China Sea and the littoral states. The other is land bordering based on the real national boundaries, mainly referring to Northeast Asia, Southeast Asia, South Asia and Central Asia. The distribution of two types is different in geographical scope, but there exists intercross and close relationship. 
The five geographical regions are shown as follows (Figure 2). One is border geo-cities in Northeast. They consist of border cities in Northeast China, North China, the northern part of East China, Bohai and the Yellow Sea, along with border cities in Russia, Mongolia, North Korea, South Korea and Japan. The second is border geo-cities in Central Asia. They consist of border cities in Northwest China and Central Asian countries bordering China. The third is border geo-cities in South Asia. They consist of border cities in Southwest China and South Asian countries bordering China. The fourth is border geo-cities in Southeast Asia. They consist of border cities in Southern China, the southern part of East China, East China Sea, and border cities in Vietnam, Laos and Myanmar bordering China. The fifth is border geo-cities in the South China Sea. They consist of China's border cities in Guangdong, Guangxi, Hainan, Hong Kong, Macao and Taiwan, and foreign border cities in Vietnam, Malaysia, Indonesia, Brunei and the Philippines, which play a vital role on the stability of the South China Sea. Five large regions involve 20 countries, 116 first-level administrative units, 5787 urban settlements, 522 border geo-cities, 5.8254 million square kilometers of land area in administrative jurisdiction, 103.9 thousand kilometers of highway mileage, and 35.5 thousand kilometers of railway mileage.

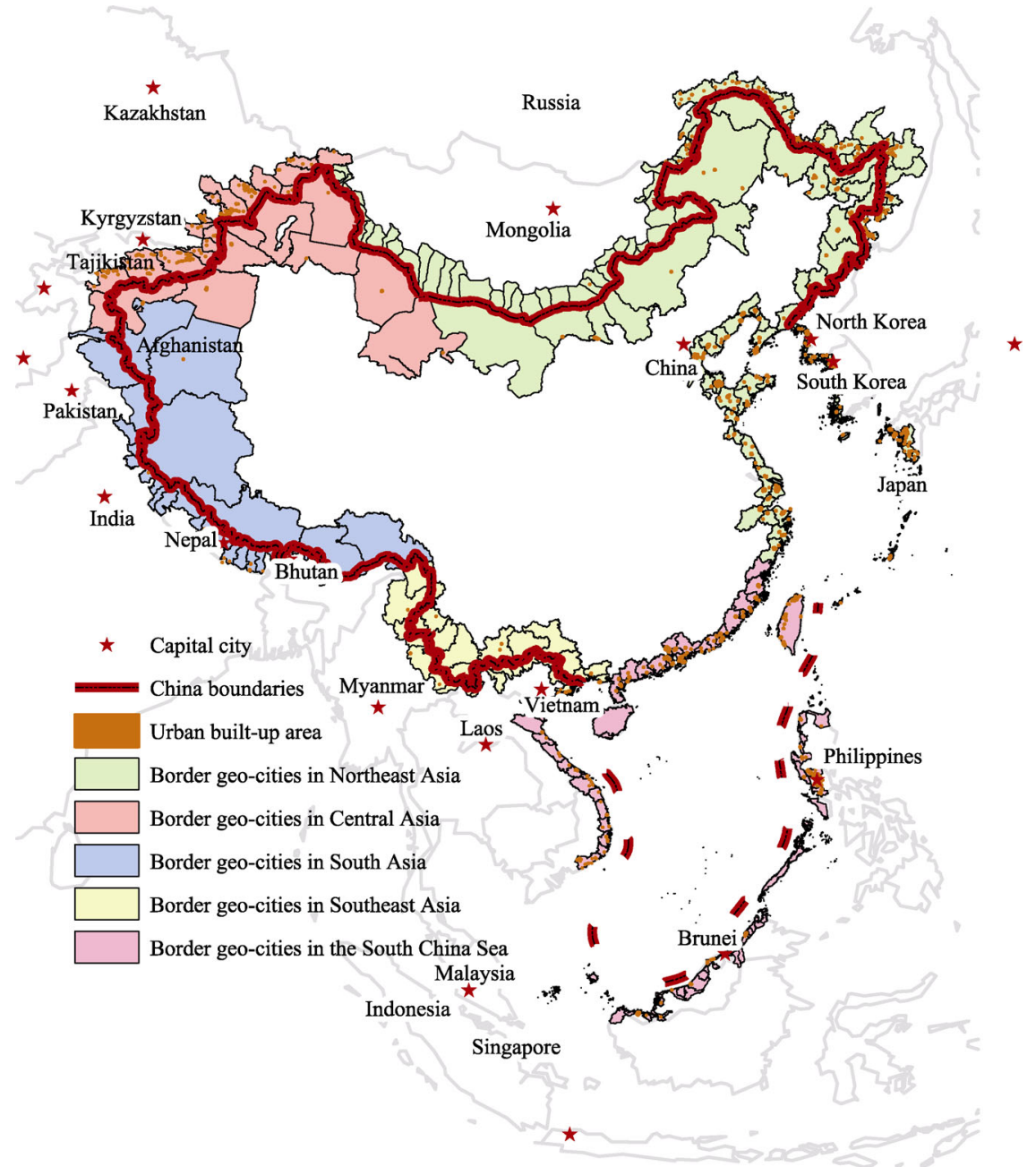

Figure 2 Classification of border geo-cities in China and the surrounding countries 


\section{Research ideas and method}

Due to the characteristics of "location" and "connection" of border geo-cities, system structure and system functions which derive from space elements (point, line and polygon) and element combination, as well as the internal and external connection in border areas are always be affected. Thus, geo-setting of border geo-cities is revealed by statistical analysis of point, line and polygon. The number of border cities represents the current development status of border region urbanization in one country. The number of urban settlements represents the future development potential impacted by point feature. The number of provincial states indicates that the policy support or administrative restriction of border cities in future development. The mileage of railway and highway reflects the infrastructure construction of border geo-cities and urban security situation. Urban land areas are regarded as an important reference for the development potential of border cities impacted by polygon feature. Based on remote sensing image interpretation of land cover and spatial statistical analysis of geographic information system, this paper demonstrates the element analysis of border geo-cities in China and the surrounding countries (Table 2). Furthermore, this paper constructs the model of urban scale potentiality to analyze the overall regional differences of border geo-cities in a quantitative way.

The calculation on regional differences of border geo-cities was done mainly by the importance model of geo-setting. The principles of model and measurement formula in detail are as follows. The important degree of border geo-cities and regions for a country in geo-setting structure is regarded as dependent variable, which is expressed by the weights of independent variable and reflects the influence and development potential of a country. Independent variables are the number of provincial states, border cities, urban settlements, urban land area, highway mileage, railway mileage, which are key influencing factors for the security and development of border geo-cities. What is more, some measures are taken to keep the objectivity and scientificity of independent variables. First of all, we clarify and classify the directions of variables. In this paper, the independent variables are divided into two classes. One is variable which means "the bigger the optimal", such as the number of border cities, urban settlements, urban land area, highway mileage, railway mileage. The greater these variable values are, the larger development space and the more reasonable structure of border geo-cities are in the region. The other is variable which means "the smaller the better", such as the provincial administrative unit. The number of provincial states is negatively correlated with urban development and expansion. The fewer the provincial states are, the better the regulation and management of border areas will be. Next, independent variable weights are set by using weight discriminated method of two-two indicators comparison. In virtue of professional knowledge and rational experience, we judge the comparative advantages and relative importance of two-two indicators. According to the comparative advantage, 5 types are set as absolute importance, very importance, comparative importance, slightly importance, and equal importance. The overall importance is greater for those indexes with more importance and comparative advantage. The greater the overall value is, the larger the final weight will be. The weight scores of independent variables are shown in Table 3.

In addition, due to the non-unified units, these mining data and analysis need to be normalized. Given the indexes with different directions, we adopt different processing methods 
Table 2 Element statistics of border geo-cities in China and the surrounding countries

\begin{tabular}{|c|c|c|c|c|c|c|c|}
\hline Regions & Countries & Provincialstates & Border cities & $\begin{array}{c}\text { Urban } \\
\text { settlements }\end{array}$ & $\begin{array}{l}\text { Urban land } \\
\text { area }\left(\mathrm{km}^{2}\right)\end{array}$ & $\begin{array}{l}\text { Highway } \\
\text { mileage }\end{array}$ & $\begin{array}{l}\text { Railway } \\
\text { mileage }\end{array}$ \\
\hline \multirow{6}{*}{$\begin{array}{l}\text { Northeast } \\
\text { Asia }\end{array}$} & China & 10 & 48 & 2158 & 1555710.14 & 30039.91 & 17490.68 \\
\hline & Russia & 5 & 37 & 298 & 322755.24 & 4691.17 & 4241.65 \\
\hline & Japan & 2 & 4 & 134 & 23240.37 & 1791.35 & 1201.88 \\
\hline & Korea & 6 & 38 & 63 & 16705.77 & 1793.03 & 274.33 \\
\hline & Mongolia & 8 & 37 & 40 & 452869.90 & 3510.03 & 470.88 \\
\hline & North Korea & 9 & 55 & 79 & 31708.76 & 2235.00 & 956.50 \\
\hline \multirow{6}{*}{$\begin{array}{l}\text { The South } \\
\text { China Sea }\end{array}$} & China & 6 & 24 & 1110 & 205469.00 & 13635.63 & 3108.09 \\
\hline & Vietnam (sea) & 18 & 87 & 137 & 32256.53 & 1304.27 & 1006.15 \\
\hline & Philippines & 4 & 15 & 279 & 56817.25 & 3697.40 & 589.99 \\
\hline & Malaysia & 2 & 37 & 93 & 52059.00 & 1915.24 & 98.94 \\
\hline & Indonesia & 2 & 2 & 15 & 8628.00 & 165.17 & 0.00 \\
\hline & Brunei & 3 & 12 & 7 & 1127.67 & 290.69 & 0.00 \\
\hline \multirow{5}{*}{$\begin{array}{l}\text { Central } \\
\text { Asia }\end{array}$} & China & 2 & 9 & 142 & 876855.55 & 7766.06 & 2410.91 \\
\hline & Kazakhstan & 2 & 12 & 115 & 189182.34 & 3778.42 & 689.69 \\
\hline & Kyrgyzstan & 3 & 3 & 88 & 122089.65 & 3420.23 & 272.51 \\
\hline & Tajikistan & 1 & 1 & 10 & 37833.77 & 645.92 & 0.00 \\
\hline & Russia & 1 & 1 & 9 & 19165.95 & 1059.78 & 0.00 \\
\hline \multirow{4}{*}{$\begin{array}{l}\text { Southeast } \\
\text { Asia }\end{array}$} & China & 2 & 13 & 359 & 271121.89 & 6375.70 & 1133.89 \\
\hline & Vietnam (land) & 7 & 33 & 59 & 27474.69 & 527.19 & 60.69 \\
\hline & Laos & 3 & 6 & 12 & 10958.98 & 347.12 & 0.00 \\
\hline & Myanmar & 2 & 9 & 138 & 142224.07 & 1675.27 & 231.85 \\
\hline \multirow{6}{*}{ South Asia } & China & 2 & 7 & 166 & 1034593.45 & 7718.72 & 649.14 \\
\hline & India & 5 & 16 & 95 & 132565.24 & 2853.63 & 459.82 \\
\hline & Nepal & 5 & 10 & 106 & 109287.97 & 1465.29 & 107.12 \\
\hline & Bhutan & 4 & 11 & 5 & 13720.72 & 0.00 & 0.00 \\
\hline & Afghanistan & 1 & 1 & 3 & 11045.68 & 208.18 & 0.00 \\
\hline & Pakistan & 1 & 1 & 67 & 67909.30 & 1024.78 & 0.00 \\
\hline
\end{tabular}

Table 3 Weight scores of independent variables

\begin{tabular}{lcccccc}
\hline $\begin{array}{c}\text { Independent } \\
\text { variables }\end{array}$ & $\begin{array}{c}\text { Provincial } \\
\text { states }\end{array}$ & $\begin{array}{c}\text { Number of } \\
\text { border cities }\end{array}$ & $\begin{array}{c}\text { Number of urban } \\
\text { settlements }\end{array}$ & $\begin{array}{c}\text { Urban } \\
\text { land area }\end{array}$ & $\begin{array}{c}\text { Highway } \\
\text { mileage }\end{array}$ & $\begin{array}{c}\text { Railway } \\
\text { mileage }\end{array}$ \\
\hline Weight scores & 0.11 & 0.33 & 0.11 & 0.17 & 0.17 & 0.11 \\
\hline
\end{tabular}

during data normalization. Normalization processing for the variables of "the bigger the optimal" is that each variable value subtracts the minimum value, and then divides the difference of maximum and minimum. Normalization processing for the variables of "the smaller the better" is that maximum value subtracts each value, and then divides the difference of maximum and minimum. The formulas are shown as follows respectively:

$$
\begin{aligned}
& a_{i j k}^{(\mathrm{s})}=\left[u_{i j k}^{(\mathrm{s})}-u_{i j k}^{(\min )}\right] /\left[u_{i j k}^{(\max )}-u_{i j k}^{(\min )}\right] \\
& a_{i j k}^{(\mathrm{s})}=\left[u_{i j k}^{(\max )}-u_{i j k}^{(\mathrm{s})}\right] /\left[u_{i j k}^{(\max )}-u_{i j k}^{(\min )}\right]
\end{aligned}
$$




$$
\begin{gathered}
C_{i}=a_{i j} * a_{w j}(j=1,2,3, \cdots, n) \\
R_{i}=\left(C_{1}+C_{2}+\ldots+C_{n}\right) / N(N=1,2,3, \ldots, n)
\end{gathered}
$$

where $u_{i j k}{ }^{(s)}$ represents the value of independent variable $j$ of country $i$ in a two-dimensional matrix $k . u_{i j k}{ }^{(\mathrm{min})}$ represents the minimum value in matrix $k . u_{i j k}{ }^{(\max )}$ represents the maximum value in matrix $k . a_{i j k}^{(s)}$ represents normalized results. $C_{i}$ represents the importance of country $i$ in border geo-cities. $a_{i j}$ refers to normalized difference index. $a_{w j}$ refers to the weight value of independent variable $j$ in the comprehensive evaluation. $R_{i}$ refers to the important degree of border geo-cities of region $i$ in China's surrounding geo-setting.

\section{Results and discussion}

According to the above-mentioned research idea and method, the paper estimates the geosetting of border geo-cities by using key elements statistics in China and the surrounding countries. The importance of borer geo-cities in spatial structure system is unveiled in Table 4.

\begin{tabular}{|c|c|c|c|c|c|c|c|c|c|}
\hline Regions & $\begin{array}{c}\text { Region } \\
\text { scores }\end{array}$ & Countries & $\begin{array}{c}\text { Countries } \\
\text { score }\end{array}$ & $\begin{array}{l}\text { Provincial } \\
\text { states }\end{array}$ & $\begin{array}{l}\text { Border } \\
\text { cities }\end{array}$ & $\begin{array}{c}\text { Urban } \\
\text { settlements }\end{array}$ & $\begin{array}{c}\text { Urban land } \\
\text { area }\end{array}$ & $\begin{array}{l}\text { Highway } \\
\text { mileage }\end{array}$ & $\begin{array}{l}\text { Railway } \\
\text { mileage }\end{array}$ \\
\hline \multirow{6}{*}{$\begin{array}{l}\text { Northeast } \\
\text { Asia }\end{array}$} & \multirow[t]{6}{*}{0.30} & China & 0.89 & 0.47 & 0.55 & 1.00 & 1.00 & 1.00 & 1.00 \\
\hline & & Russia & 0.27 & 0.76 & 0.42 & 0.14 & 0.21 & 0.16 & 0.24 \\
\hline & & Japan & 0.15 & 0.94 & 0.03 & 0.06 & 0.01 & 0.06 & 0.07 \\
\hline & & Korea & 0.15 & 0.71 & 0.43 & 0.03 & 0.01 & 0.06 & 0.02 \\
\hline & & Mongolia & 0.17 & 0.59 & 0.42 & 0.02 & 0.29 & 0.12 & 0.03 \\
\hline & & North Korea & 0.16 & 0.53 & 0.63 & 0.04 & 0.02 & 0.07 & 0.05 \\
\hline \multirow{6}{*}{$\begin{array}{l}\text { The South } \\
\text { China Sea }\end{array}$} & \multirow[t]{6}{*}{0.19} & China & 0.40 & 0.71 & 0.27 & 0.51 & 0.13 & 0.45 & 0.18 \\
\hline & & $\begin{array}{l}\text { Vietnam } \\
\text { (sea) }\end{array}$ & 0.15 & 0.00 & 1.00 & 0.06 & 0.02 & 0.04 & 0.06 \\
\hline & & Philippines & 0.18 & 0.82 & 0.16 & 0.13 & 0.04 & 0.12 & 0.03 \\
\hline & & Malaysia & 0.18 & 0.94 & 0.42 & 0.04 & 0.03 & 0.06 & 0.01 \\
\hline & & Indonesia & 0.11 & 0.94 & 0.01 & 0.01 & 0.00 & 0.01 & 0.00 \\
\hline & & Brunei & 0.11 & 0.88 & 0.13 & 0.00 & 0.00 & 0.01 & 0.00 \\
\hline \multirow{5}{*}{ Central Asia } & \multirow[t]{5}{*}{0.16} & China & 0.27 & 0.94 & 0.09 & 0.06 & 0.56 & 0.26 & 0.14 \\
\hline & & Kazakhstan & 0.18 & 0.94 & 0.13 & 0.05 & 0.12 & 0.13 & 0.04 \\
\hline & & Kyrgyzstan & 0.14 & 0.88 & 0.02 & 0.04 & 0.08 & 0.11 & 0.02 \\
\hline & & Tajikistan & 0.12 & 1.00 & 0.00 & 0.00 & 0.02 & 0.02 & 0.00 \\
\hline & & Russia & 0.12 & 1.00 & 0.00 & 0.00 & 0.01 & 0.04 & 0.00 \\
\hline \multirow{4}{*}{$\begin{array}{l}\text { Southeast } \\
\text { Asia }\end{array}$} & \multirow[t]{4}{*}{0.16} & China & 0.24 & 0.94 & 0.14 & 0.17 & 0.17 & 0.21 & 0.06 \\
\hline & & $\begin{array}{l}\text { Vietnam } \\
\text { (land) }\end{array}$ & 0.13 & 0.65 & 0.37 & 0.03 & 0.02 & 0.02 & 0.00 \\
\hline & & Laos & 0.11 & 0.88 & 0.06 & 0.00 & 0.01 & 0.01 & 0.00 \\
\hline & & Myanmar & 0.16 & 0.94 & 0.09 & 0.06 & 0.09 & 0.06 & 0.01 \\
\hline \multirow{6}{*}{ South Asia } & \multirow[t]{6}{*}{0.15} & China & 0.26 & 0.94 & 0.07 & 0.08 & 0.66 & 0.26 & 0.04 \\
\hline & & India & 0.15 & 0.76 & 0.17 & 0.04 & 0.08 & 0.09 & 0.03 \\
\hline & & Nepal & 0.13 & 0.76 & 0.10 & 0.05 & 0.07 & 0.05 & 0.01 \\
\hline & & Bhutan & 0.11 & 0.82 & 0.12 & 0.00 & 0.01 & 0.00 & 0.00 \\
\hline & & Afghanistan & 0.11 & 1.00 & 0.00 & 0.00 & 0.01 & 0.01 & 0.00 \\
\hline & & Pakistan & 0.13 & 1.00 & 0.00 & 0.03 & 0.04 & 0.03 & 0.00 \\
\hline
\end{tabular}

Table 4 The importance of countries and regions in spatial structure system of borer geo-cities 
From the weight scores of variables and the importance in spatial structure system of border geo-cities, it can be seen that in terms of geopolitical security and regional development, the analysis in national dimension and in border cities dimension for the same geographical region produces rather different results. The priority of geo-setting security and development in China's surrounding areas is Northeast Asia, the South China Sea, Central Asia, Southeast Asia and South Asia. The priority of security and economic development of China's border cities are Northeast Asia, the South China Sea, Central Asia, South Asia and Southeast Asia. In general, as for the development environment of geo-cities in China's border areas, the east is significantly better than the west, and the north is slightly better than the south. The differences of regional spatial structure about the security and development of border geocities are closely related to the strategic positioning, national status, comprehensive strength of large regions, neighboring countries and border cities.

\subsection{Border geo-cities in Northeast Asia having better development conditions and ob- vious traffic advantages}

Border geo-cities in Northeast Asia cover 40 provincial states, 2772 dispersed urban settlements, 2.403 million square kilometers of urban land areas, which account for more than $40 \%$ of the overall border geo-cities in China's surrounding area (Table 4). In terms of the importance of regions in the spatial structure of geo-cities, Northeast Asian gains the highest score (0.30), and China in this region also obtains score as high as 0.89 . Compared to other regions, border geo-cities in Northeast Asia have better development conditions and favorable environment.

The characteristics of border geo-cities in Northeast Asia are as follows. First, they have superior natural geographical environment. Except Inner Mongolia with plateau terrain, other areas in Northeast Asia are plains and hilly terrain. The Northeast China Plain, North China Plain and Yangtze Plain not only provide materials for the development of cities, but also save greatly transportation cost and communication cost. Besides, this region has humid climate, adequate water, convenient resource transportation, broad market demands, long history and colorful culture, good foundation for industrial development. All of these make Northeast Asia a preferred region for opening up and development of China's border area. Second, this region has good open and development policies. In China, Northeast Asia region has the strategic policies of opening up and development of coastal area and border area. In the overseas, it has vast international markets such as Japan, Russia, South Korea, North Korea and Mongolia. All provide a perfect foundation for the full play of boundary effect. Third, this region has many border ports and cities. The distribution of border geo-cities in Northeast Asia is intensive. Many urban settlements are formed along rivers, bridges, highway and railway. In some areas with relatively favorable geographical conditions, many frontier ports come into being. Border cities and regional center cities not far from frontier ports also develop quickly and become the hinterlands. In addition, the corresponding relationships between ports and cities lay a good foundation for opening up and development of geo-cities in Northeast Asia. Fourth, this region has obviously comparative advantages of transportation. In the range of 2.403 million square kilometers of urban land areas in Northeast Asia, highway mileage reaches 44,060.49 kilometers, which accounts for $42 \%$ of the total mileage in China's surrounding areas. Railway mileage is 24,635.92 kilo- 
meters, accounting for 69\%. Both highway and railway mileage reach 68,696.41 kilometers, exceeding $50 \%$ of the overall land transport.

\subsection{Geo-cities in the South China Sea having intensive spatial distribution and out- standing security issue}

The South China Sea has broad waters, fewer lands and cities, while it involves many countries and regions. Although fewer land areas do border cities cover, the region includes many provincial states at home and abroad. Including six countries bordering the South China Sea with 3.5 million square kilometers of waters, this region involves 35 related second-level administrative units, 177 border cities and 1641 urban settlements, which account for $28 \%$ of the total border geo-cities in China's surrounding areas. The regional score in the South China Sea is 0.19 , next to Northeast Asia. China's score is 0.4 in this region, significantly higher than other five countries.

The characteristics of border geo-cities in the South China Sea are as follows. First of all, the spatial distribution of geo-cities in South China Sea is intensive, and the size of urban settlements is large. From spatial patterns, it presents long and narrow stripes for the distributions of geo-cities in China, Philippines, Vietnam, Malaysia, Indonesia and Brunei, by which the South China Sea is surrounded. As for the distance from border cities to their political centers, other countries have shorter distance than China. With regard to the distribution of built-up areas of cities with a certain scale, Guangdong, Macao and Taiwan in China and Manila in the Philippines are more prominent in the South China Sea. The number of China's urban settlements is the largest in this region. There are 1110 urban settlements within the range of 24 border cities in Guangdong, Fujian, Hainan, Hong Kong, Macao and Taiwan, which demonstrates that China's southeast coast is densely populated in the surrounding geo-setting of the South China Sea. Second, aviation and pipeline are major transportations. Due to the restriction of sea waters, there are no highway and railway. Scattered airports, shipping routes and submarine pipelines are the predominant transportations. Third, the security of border geo-cities in the South China Sea is a striking problem. The territory and ownership of resources are still in dispute. This region is one of the most complex areas of international relations in China's surrounding geo-setting. Countries neighboring the South China Sea having sovereignty disputes with China are the main bodies, which produce the conflict of the South China Sea and directly determine the security of border geo-cities. From the perspectives of geographical location, regional countries and interregional links, the geopolitical bodies of the South China Sea can be classified into three major types: intra-area counties, the intervening countries outside the area and associated international organizations (Hu H et al., 2012).

\subsection{Geo-cities in Central Asia developing slowly and having significant value of stra- tegic corridor}

Central Asia is a region with vast territory but sparsely populated. Border cities encompass few provincial states ranging from 1 to 3. Jurisdiction of first-level administrative units for countries is relatively large. The number of border provinces, border cities and urban settlements is the least in Central Asia. Regional score of Central Asia is 0.16, and China's score in this region is 0.27 . 
The characteristics of border geo-cities in Central Asia are as follows. Firstly, the spatial distribution of border geo-cities is sparse. The distribution of border cities or urban settlements is along the main traffic routes or assembled around scattered oasis or lakes. Secondly, air transportation is the primary way of traffic. Central Asia is located in inland with mostly mountainous plateaus. Highways and railways are fewer compared to other regions. Nevertheless, in some key nodes and important positions, there are traffic arteries or dual-use airports for the circulation of materials, persons and goods. In border areas of Central Asia, it is the regional characteristics of border geo-cities that using sparse air transportation and ports to maintain the security, stability and development of cities. The airport advantage in this region is far more than highway and railway. Thirdly, border geo-cities of Central Asia have great strategic significance for China. The development conditions in Central Asia are not desirable, which is drought and having many problems of transnational ethnic groups and terrorist activities. Yet it is a significant strategic corridor for China to connect West Asia and Europe. The comprehensive strength of Central Asian countries and their locations are always impacting the security and stability of border geo-cities in western China.

\subsection{Geo-cities in Southeast Asia having complex administrative division and the vast potential for regional cooperation}

The region of Southeast Asia involves 14 related provincial states, 61 border cities, 568 urban settlements above designated size, accounting for $12 \%, 12 \%$ and $10 \%$ of the total respectively. The regional score of Southeast Asia is nearly the same as that of Central Asia 0.16 . China's score in this region is 0.24 .

The characteristics of border geo-cities in Southeast Asia are as follows. First, Vietnam is dominant in the number of border geo-cities. It has the largest number of border cities with 33 municipal level cities in 27,474.69 square kilometers of land area, which accounts for more than half of the total border cities. But the urban settlements are only 59. Second, administrative division is complex, and the standards are different. The size of administrative divisions in Myanmar is similar to that of China, yet the size of administrative divisions in Laos and Vietnam are much smaller and denser than that of southwest China. As for the built-up areas of cities, border geo-cities in Southeast Asia have fewer large-scale cities and built-up areas. Only in administrative center cities, can border cities with large scale built-up areas be observed, such as Kunming - the provincial capital of Yunnan, Hu Zhiming city the capital of Vietnam. Third, the development of border geo-cities in this region is uneven. The development of border geo-cities in China is the highest owing to the combined effects of elements of point, line and polygon, for instance airports, highway ports, urban settlements, cross-border highways and rivers, built-up areas of cities and urban scale. The development of border geo-cities in Myanmar is the second to China. The lands bordering mileages between Myanmar and China in this region are the most. Although the number of border cities is small, the number of urban settlements is large. The development level of border geo-cities in Vietnam and Laos just reaches the half of China. Fourth, the development of port economy is comparatively mature. The region of Southeast Asia has a lot of border ports with 12 first-class ports and 8 second-class ports in China's Yunnan Province. Port hinterland shaped by open border ports forms the invisible space and constantly expands, which become an important part of polygon element of spatial structure. It not only 
plays an essence role in southwestern China, but also plays an irreplaceable role in the international trade and logistics flow in the overall Southeast Asia.

\subsection{Geo-cities in South Asia having obviously dense distribution and greatly develop- ing difference}

The region of South Asia covers 18 related provincial states, 46 border cities, 442 urban settlements, accounting for $16 \%, 9 \%$ and $8 \%$ of the total respectively. They are far fewer than those in Northeast Asia and the South China Sea. The regional score of South Asia is the lowest (0.15). China's score in this region is 0.26, slightly higher than that in Southeast Asia.

The characteristics of border geo-cities in South Asia are as follows. Firstly, the dense distribution difference of border geo-cities is obvious. The distribution in China is sparse, while the distribution in India, Nepal and Pakistan is concentrated. In particular, there are more large-scale cities in Indian and Pakistani border areas. Secondly, the distribution of traffic lines is sparse. There are few highways and railways in geo-cities region along the national boundaries of India, Nepal, Bhutan, Afghanistan and Pakistan. There is only one highway linking Xinjiang and Tibet in China's border. All indicate that the terrain of the Himalaya Mountains and geographical barrier indeed generates "barrier zone effect" to some extent. Plateau terrain, ice cover and harsh climatic conditions do produce many negative effects on the construction of traffic infrastructure. Thirdly, owing to the particularity of terrain, topography, climate and weather in border cities of South Asia, the construction of highway and railway as well as the development of urban settlements are slightly backward than those in other regions. The proportion of railway mileage in border geo-cities of South Asia is the smallest, only accounting for $3 \%$. Among six countries, just three countries namely China, India and Nepal have a few railways in border cities. In South Asia, the development of infrastructure, industries and agriculture in China's border geo-cities lags behind India, which is a distinguishing feature in South Asia compared to other regions.

In summary, we not only find the different distributed number, location characteristics in different border region in China and the surrounding countries, but also get some element statistics and the importance of countries and regions in spatial structure system of borer geo-cities. Based on the remote sensing information acquisition, the geo-statistical analysis in ArcGIS, we calculate the number of border cities, urban settlements, provincial states and the mileage of railway and highway which represents the current development status, the future potentiality, the policy support or administrative restriction, the infrastructure construction of border region urbanization and development. By setting dependent variable, independent variables, weight scores of independent variables, their relationship, computing formulas and adopt different processing methods during data normalization, we measure the important degree of border geo-cities and regions for a country in geo-setting structure. And the results of geo-setting evaluation of border geo-cities in China and surrounding countries well match the geo-politics of China's surrounding international environment correspondence. Such as the Security Issue of the South China Sea, the Strategic Corridor and new Silk Road developments in Central Asia, the Traffic Advantages of China in Northeast Asia, the Potentiality for Regional Cooperation in Southeast Asia, the complex international relations in South Asia and so on. With the help of new technology and analysis method in the analysis of the geographical environment and the background of the international relations, 
we can get more cross-border information of urban spatial and regional development, thus there will be more quantitative evaluation and more scientific inference for the development of cities and the security of border regions in future.

\section{Conclusions and future research}

Based on the interdisciplinary perspectives of urban geography, regional economics and geopolitics, this paper explores the regional differences of border geo-cities in China and the surrounding countries by using the remote sensing information acquisition and ArcGIS spatial analysis. The main conclusions are drawn as follows.

(1) Based on world geographical regionalization and geopolitical situation in China's surrounding area, and given the comprehension of sea-land coordination, along with domestic and international balance, border geo-cities in China and the surrounding countries are divided into five geographical regions: geo-cities in South China Sea, geo-cities in Southeast Asia, geo-cities in South Asia, geo-cities in Central Asia and geo-cities in Northeast Asia.

(2) The paper reveals the importance of regions and counties in spatial structure system through constructing the scale potential model of border geo-cities. According to the regional scores, the rank of priority of safety and economic development of China's border geo-cities is geo-cities in Northeast Asia, geo-cities in South China Sea, geo-cities in Central Asia, geo-cities in Southeast Asia and geo-cities in South Asia.

(3) The characteristics of border geo-cities in China and the surrounding countries are as follows. Border geo-cities in Northeast Asia have good natural geographical conditions, obvious traffic advantages, dense urban settlements and many port cities. Geo-cities in the South China Sea develop maturely with the intensive distribution of coastal border cities and large-scale urban settlements. But the security issue of border areas is outstanding. Geo-cities in Central Asia have sparse distribution, few urban settlements, yet having the position of significant strategic corridor for China. Trades among countries are carried out through the ports connected by cross-border highways. Geo-cities in Southeast Asia have a lot of border ports, the complex administrative division, and the vast potential for regional cooperation. Geo-cities in South Asia have the different dense distribution, few traffic lines and less developed compared to other regions.

(4) The reasons for the regional differences of border geo-cities in China and the surrounding countries are analyzed. Location and connection lead to regional differences in border scales. The differences are gradually enlarged owing to the human segmentation and geographical barrier of settlements, national boundary, ridge line and valley line, river and lake. Meanwhile, the differences are steadily diminishing because of tangible and intangible connection with the bilateral trades, cross-border traffic lines, cross-border ethnic areas, entry and exit ports. Finally, the differences of regional distribution between core and periphery appear attributing to neighbor or not, connection frequency and interdependent coefficients. The development and changes of these differences produce new differences in urban scale, grade structure, development potentiality and functions of border geo-cities.

The future research on border geo-cities can be conducted in the following aspects: the influence factors and mechanism of regional differences of border geo-cities; the driving factors of border geo-cities development; the quantitative analysis of security and develop- 
ment for border geo-cities; the evaluation model of security and development; the comparative study of typical border cities; analysis on development orientation and regional orientation of border geo-cities. What is more, as the limitation of coverage, the accuracy of interpretation in terms of remote sensed/satellite images, field investigation, perhaps some involving local field work should be promoted to get more accurate Land Use/Land Cover data and deeper geographic information analysis.

\section{References}

Anishchenko A, Sergunin A, 2012. Twin cities: A new form of cross-border cooperation in the Baltic Sea Region? Baltic Region, 1(11): 27-38.

Buursink J, 2001. The bi-national reality of border-crossing cities. GeoJournal, 54: 7-19.

Champion A, 2001. A changing demographic regime and evolving polycentric urban regions: Consequences for the size, composition and distribution of city populations. Urban Studies, 38: 657-677.

Cherpitel C J, Ye Y, Bond J et al., 2015. Border effects on DSM-5 alcohol use disorders on both sides of the U.S.-Mexico border. Drug \& Alcohol Dependence, 148(3): 172-179.

Dürrschmidt J, 2006. So near yet so far-blocked networks, global links and multiple exclusion in the German-Polish borderlands. Global Networks, (3): 245-263.

Ehlers N, Buursink J, Boekema F, 2001. Bi-national cities and their regions: From diverging cases to a common research agenda. GeoJournal, 54: 1-5

Eskelinen H, Kotilainen J, 2004. Imatra-Svetogorsk: Kaupunkiparista kaksoiskaupungiksi. Idäntutkimus, 1: 2835.

Fang Xiaoping, Li Peng, Ding Sibao, 2011.The gradient structure and the echelon development value of the value of the border area: A case of the border area along China and the ASEAN countries. Economic Geography, 31(9): 1409-1413. (in Chinese)

Fanni Z, Khakpour B A, Heydari A, 2014. Evaluating the regional development of border cities by TOPSIS model: Case study Sistan and Baluchistan Province, Iran. Sustainable Cities and Society, 10: 80-86.

$\mathrm{Gu}$ Lin, 2010. Research on cross-border economic cooperation in inland border of frontier area: Take Suifenhe city of Heilongjiang province as example [D]. Changchun, China: Jilin University. (in Chinese)

Guo Rongxing, 2012. US-Mexico border environment cooperation. Developments in Environmental Science, (10): 279-305.

Guo Wenjun, 2009. Research on Yanbian economic development strategy in Tumen River regional cooperation [D]. Yanbian, China: Yanbian University. (in Chinese)

Hanson G H, 2001. US-Mexico integration and regional economies: Evidence from border-city pairs. Journal of Urban Economics, 50(2): 259-287.

Heyman J M, 2001. Class and classification at the US-Mexico border. Human Organization, 60(2): 128-140.

$\mathrm{Hu}$ Hao, Ge Yuejing, Hu Zhiding, 2012. The geopolitical environment of greater neighborhood of the South China Sea. World Regional Studies, 21(3): 36-44. (in Chinese)

$\mathrm{Hu}$ Zhiding, Luo Huasong, Li Cansong et al., 2012. Triple functions of country border and its concerning optimized combination under the perspective of geopolitical security. Human Geography, 27 (3): 73-77. (in Chinese)

Javed S, 2014. Role of socio cultural factors in depression among elderly of twin cities (Rawalpindi and Islamabad) of Pakistan. Current Gerontology and Geriatrics Research, 1-5. http://dx.doi.org/10.1155/2014/230737.

Johnson C M, 2009. Cross-border regions and territorial restructuring in central Europe: Room for more transboundary space. European Urban and Regional Studies, 16(2): 177-191.

Kosonen R, Loikkanen K, 2005. Twin cities or paired border cities? Three case studies from the Finnish border. Paper presented at the Inaugural Nordic Geographers Conference, May, 11-13, Lund University, Sweden.

Krätke S, 1999. Regional Integration or fragmentation? The German-Polish border region in a new Europe. Regional Studies, 33(7): 631-641. 
Laura M N, Mark F, Phillip G, 2009. Forecasting urban growth across the United States-Mexico border. Computers, Environment and Urban Systems, (33): 150-159.

Li Huijuan, 2010. The development model of Chinese frontier port cities [D]. Beijing, China: Central Minzu University. (in Chinese)

Lunden T, Zalamans D, 2001. Local cooperation, ethnic diversity and state territoriality: The case of Haparanda and Tornio on the Sweden-Finland border. GeoJournal, 54: 33-42.

Ma Bo, 2011. Study on regional economic integration in China's border area [D]. Beijing, China: Central Minzu University. (in Chinese)

Marcelli E A, Cornelius W A, 2001. The changing profile of Mexican migrants to the United States: New evidence from California and Mexico. Lat. Am. Res. Rev., 36: 105-131.

Markus P, 2005. The construction of new scales: A framework and case study of the Euregio cross-border region. CSGR Working Paper, No.165/05.

Meijers E, Hoogerbrugge M, Hollander K, 2014. Twin cities in the process of metro-polisation. Urban Research \& Practice, 7(1): 35-55.

Mikhailova E V, 2013. Appearance and appliance of the twin-cities concept on the Russian-China's border. ISPRS: International Archives of the Photogrammetry, Remote Sensing and Spatial Information Sciences, XL-4/W3: 105-110.

Miguel G C, Cuauhtémoc S R, Sharada V et al., 2014. Supply chain dynamics and the "cross-border effect": The U.S.-Mexican border's case. Computers \& Industrial Engineering, 72: 261-273.

Odile H, 2001. The bi-national cities of Dover and Calais and their region. GeoJournal, 54(1): 61-71.

Ramos R, Ferreira-Pinto J O B, Brouwer K C et al., 2009. A tale of two cities: Social and environmental influences shaping risk factors and protective behaviors in two Mexico-US border cities. Health \& Place, 15(4): 999-1005.

Riitta K, Xu F, Erja K, 2008. Paired border towns or twin cities from Finland and China. Chinese Journal of Population, Resources and Environment, 6(1): 3-13.

Shi C, Fernando H J, Yang J, 2009. Contributors to ozone episodes in three US/Mexico border twin-cities. Science of the Total Environment, 407(18): 5128-5138.

Simon M, Grant M, 2004. Cross-border post-secondary education in the Asia-Pacific region. In: Internationalization and Trade in Higher Education: Opportunities and Challenges. Oraganisation for Economic Co-operation and Development Publishing, 137-204.

Song Yang, Wang Shijun, 2006. Study on the transnational integrative development of geo-cities. Areal Research and Development, 25(1): 62-66. (in Chinese)

Wu Haojun, 2011. The strategies of cross-border twin-city integration: A comparative analysis between San Diego-Tijuana twin-city and Hong Kong-Shenzhen twin-city. Urban Planning International, 26(4): 69-73. (in Chinese)

Wu Y A, 2012. Study of conditions for the success of international exchange and cooperation in cross-border cities networks: The case of 'Busan-Fukuoka cross-border Megaregion' in Northeast Asia. The Korean Journal of Local Government Studies, 16(3): 31-50.

Wu Bing, Wang Yafeng, Tong Yukai, 2012. Study on the interaction mechanism between the border ports and cities in the hinterland. Urban Development Studies, 19(9): 32-38. (in Chinese)

Yan Xiaopei, Leng Yong, 1997. Study on the coordinative development of Shenzhen-Hong Kong twin cities. Acta Geographica Sinica, 52(Suppl.1): 95-103. (in Chinese)

Zhang Jun, Li Lan, 2002. The border city development of western China under the background of western development. Journal of Guangxi University (Philosophy and Social Science), 24 (2): 48-52. (in Chinese)

Zhou Yixing, Zhang Li, 2001. The foreign-oriented hinterland of Chinese port-cities. Scientia Geographica Sinica, 21(6): 481-487. (in Chinese)

Zhu Yuanyuan, Wang Shijun, Feng Zhangxian, 2011. The central place system structure and formation mechanism research of the Chinese northeastern border area center. Economic Geography, 31(5): 724-729. (in Chinese) 